TECHNICAL TRANSACTIONS 9/2019

CIVIL ENGINEERING

DOI: $10.4467 / 2353737$ XCT.19.102.10884 SUBMISSION OF THE FINAL VERSION: $27 / 08 / 2019$

\author{
Dagmara Adamkiewicz \\ dagmara.adamkiewicz@gmail.com
}

Elżbieta Radziszewska-Zielina (D) orcid.org/0000-0002-3237-4360

eradzisz@izwbit.wil.pk.edu.pl

Institute of Management in Construction, Cracow University of Technology

\title{
A HOUSING MARKET ANALYSIS FOR THE CITY OF KRAKOW
}

\section{ANALIZA RYNKU NIERUCHOMOŚCI MIESZKANIOWYCH \\ W MIEŚCIE KRAKÓW}

\begin{abstract}
This article presents the results of a housing market analysis for the city of Krakow. The market study was performed in May 2019 using the online survey method on a group of 104 persons who were currently searching for an apartment. Based on initial studies, the authors analysed the opinions of potential customers, identified the apartments enjoying the highest demand, described the preferences of potential buyers and the criteria that encourage buying real estate to the greatest extent. Based on the results of the study, it can be concluded that the perceived need for persons to have their own apartment is the most common reason for purchasing a property. The most desirable housing has between 40 and 60 square metres of usable floor area, is composed of three rooms, in addition to a kitchen and a bathroom, and has its own dedicated parking space.
\end{abstract}

Keywords: housing market, preferences, Krakow

\section{Streszczenie}

W artykule przedstawiono wyniki badań dotyczące analizy rynku nieruchomości mieszkaniowych w Krakowie. Badania rynku zostały przeprowadzone metodą ankiety internetowej w maju 2019 roku na grupie 104 osób aktualnie poszukujących mieszkania. Na podstawie przeprowadzonych badań pierwotnych autorzy przeanalizowali opinie potencjalnych klientów, wskazali, na jakie mieszkania jest największe zapotrzebowanie, opisali preferencje potencjalnych nabywców oraz kryteria, które najbardziej zniechęcają do zakupu nieruchomości. Z wyników badań wynika, że potrzeba posiadania własnego mieszkania jest najczęstszym powodem kupna nieruchomości. Najbardziej pożądane mieszkanie ma od 40 do $60 \mathrm{~m}^{2}$, składa się z trzech pokoi, kuchni i łazienki oraz posiada własne miejsce parkingowe.

Słowa kluczowe: rynek nieruchomości mieszkaniowych, preferencje, Kraków 


\section{Introduction}

Studies associated with the real estate sector have been conducted all over the world for many years. Using the regression model, Tsai, Chang \& Tzang [15] studied how external factors such as economic growth and taxation affect apartment prices in Taiwan. Similar studies were conducted in Italy investigating whether the introduction of real estate taxes had weakened the construction sector [3]. Housing demand in northern France has also been investigated [7]. Housing development must take into consideration the needs and demands of potential apartment buyers. Numerous studies concerning the preferences of residents have been performed. Farraz \& Barus [6] investigated the housing preferences of the residents of Depok, Indonesia through the collection of data using survey and interview methods. Location can be defined using various methods, either with regard to the actual geographical location, or relative to other sites and places. As Heyman \& Sommervoll [10] pointed out on the example of Oslo, relative location has a direct influence on the price of houses. Furthermore, Zhang, Zhou, Hui \& Wen [16], when analysing apartment price data in the area of influence of the West Intime shopping mall in Hangzhou, demonstrated the impact of the distance from the analysed shopping mall on housing prices. A similar study was performed by Rivas, Patil, Hristidis, Barr \& Srinivasan [12], who analysed the impact of the location of universities and hospitals on the local real estate markets; after analysing apartment prices for a period of seven years, they demonstrated that the proximity of these buildings causes a significant increase in property prices. Affuso, Caudill, Mixon \& Starnes [1] assessed the impact of noise levels within the area of an airport in the United States on property value. Del Giudice, De Paila, Francesca, Nijkamp \& Shapira [5] developed a decision-making support system for choosing properties based on key factors that define the attractiveness of a property.

The real estate sector in Poland has also been the subject of numerous studies and analyses. Kowalczyk, Kil \& Kurowska [11] analysed the dynamics of change in the urban spaces of Polish cities. Szczepańska [13] used the example of Olsztyn to analyse the impact of real estate market processes on the selection of a place of residence. Various needs of potential buyers have also been analysed for many years. Głuszak \& Marona [9] discussed the link between the socio-economic characteristics of apartment buyers and their property choices concerning geographical location. They developed a discrete model that studies housing preferences that affect the selection of apartment locations in Krakow. Gluszak [8] conducted a cycle of studies of housing demand and preferences in Krakow over a period of six years using the regression model to demonstrate a link between neighbourhood amenities and housing prices. On the example of Krakow, Butryn \& Preweda [4] analysed the primary real estate market in the context of parking spaces. Public transport in large urban agglomerations is one of the main means of travel for many people; this was studied by Trojanek \& Głuszak [14] who analysed the impact of the presence of the underground railway on housing prices using the example of Warsaw. They found proof that the presence of a rapid urban railway has a direct affect upon the value of nearby real estate.

The effectiveness of the use of marketing tools in real estate trading was described by Belniak \& Radziszewska-Zielina [2], which included a presentation of an analysis of various 
marketing tools, the frequency of their use and the effectiveness of marketing measures. The authors of this study used primary data that was obtained using a survey.

The goal of this study was the analysis of the housing market. The study focused on Krakow, an agglomeration with a population of 750 thousand people that constitutes one of the largest Polish academic and cultural centres. It presents the results of a survey concerning the preferences of potential apartment buyers. The most desirable apartment locations, the characteristics of a perfect property and the criteria that encourage the purchase of a dwelling are indicated.

\section{Research methods}

An online survey study was performed in May 2019. The research tool that was used was an online questionnaire, a link to which had been posted on online portals frequented by persons searching for an apartment in Krakow. The questionnaire featured closed questions and a section that provided with information concerning respondents. It was constructed using questions which had either a nominal or an ordinal scale which was used by respondents to determine the significance of criteria and factors affecting property purchases, as well as an it was using interval scale which was used by to order the criteria according to size and dimension to appropriate sets. The study was conducted using nonprobability sampling, with the target group displaying specific traits. These were persons who declared a desire to purchase property in the near future in the city of Krakow, and were interested in both the primary and secondary markets.

The study was designed to identify which apartments were the most likely to be selected by buyers and was used to procure knowledge of client preferences concerning housing standards and location. The study aided in characterising the group of people generating demand and made it possible to determine the key criteria during the selection of a property, as well as those that encourage property purchases. The analysis of the results of the study identified the most desirable of Krakow's districts in terms of housing and also indicated which location displayed the greatest attractiveness. The studies helped to define the differences between the apartment preferences with regard to the motive behind their purchase.

\section{Results}

\subsection{Respondent characteristics}

The sample was composed of 104 persons, $65 \%$ were women and $35 \%$ were men. Effective demand supported by financial means was formed primarily by young persons with a higher education who were gaining professional experience and had an average or above-average income. The most numerous group among the respondents was comprised of persons below 30 years of age, constituting as much as $75 \%$ of all respondents. Of the persons comprising 
the sample, $16 \%$ were in the 31-40 age group, with persons above 41 years of age constituting $5 \%$. The greatest interest in the real estate market was displayed by persons forming twoperson households (47\%), with persons in a three-person family model comprising $20 \%$ of respondents and $19 \%$ of the sample being comprised of single-person households. The remaining respondents $(14 \%)$ were a part of large families, comprised of four or more members.

Within the housing property market, we can distinguish the primary market, in which $62 \%$ of respondents reported, and the secondary market, in which the remaining $38 \%$ were interested.

\subsection{Preferred location}

Apartment prices and interest in the property sector were highly varied and were dependent upon the area of the city. This was confirmed by secondary studies conducted on the basis of data published by the National Bank of Poland. This data concerns both listed and transaction prices per square metre of usable apartment floor area. The data stated that the most expensive properties were in the centre of Krakow, in the Stare Miasto, Grzegórzki and Prądnik Czerwony districts. These districts are characterised by compact development, with numerous townhouses and historical buildings, with their attractive locations significantly increasing the property value. Prices in these areas were high, even exceeding $10,000 \mathrm{PLN} / \mathrm{m}^{2}$. The western area of the city - Krowodrza - was also characterised by high property prices. Nowa Huta has been the area with the cheapest apartments for many years.



Fig. 1. Respondent interest in the various areas of Krakow in terms of the location of residential properties (by authors) 
The respondents were asked to indicate the district of Krakow in which they would like to purchase an apartment. Interest in the individual districts is presented in Fig. 1. The results of the study indicate that the respondents displayed the greatest interest in the Krowodrza and Bronowice districts (20\% and $16 \%$, respectively). Stare Miasto, a district located in the central part of the city, was reported as preferred by $9 \%$ of respondents. It was claimed by $15 \%$ of respondents that the district in which they were to buy their property did not matter to them. The respondents showed no interest in the following districts: Wzgórza Krzesławickie, Bieżanów-Prokocim, Swoszowice and Łagiewniki-Borek Fałęcki.

\subsection{Motivation behind the purchase of property}

More than a half of the respondents (52\%) reported that they were renting an apartment or a room in an apartment at the time of filling out the survey; $24 \%$ reported owning an apartment or a house, $19 \%$ reported living with their parents, and only $5 \%$ of respondents declared their current inhabited to be a hall of residence for students.

The motivations for the purchase of property were varied, affected mostly by the respondents' current personal, professional and financial situation, with the reported motives for the purchase of property presented in Fig. 2. The group of respondents reporting the need to have their own apartment as the reason for the purchase of property was the largest (43\%). Respondents wanting to purchase property in order to invest money amounted to $20 \%$. These persons were often over 30 years of age and were characterised by significant financial means at their disposal and the ownership of at least one piece of property - a house or an apartment that they resided in - with the purchase of an apartment being considered as a form of increasing their wealth.

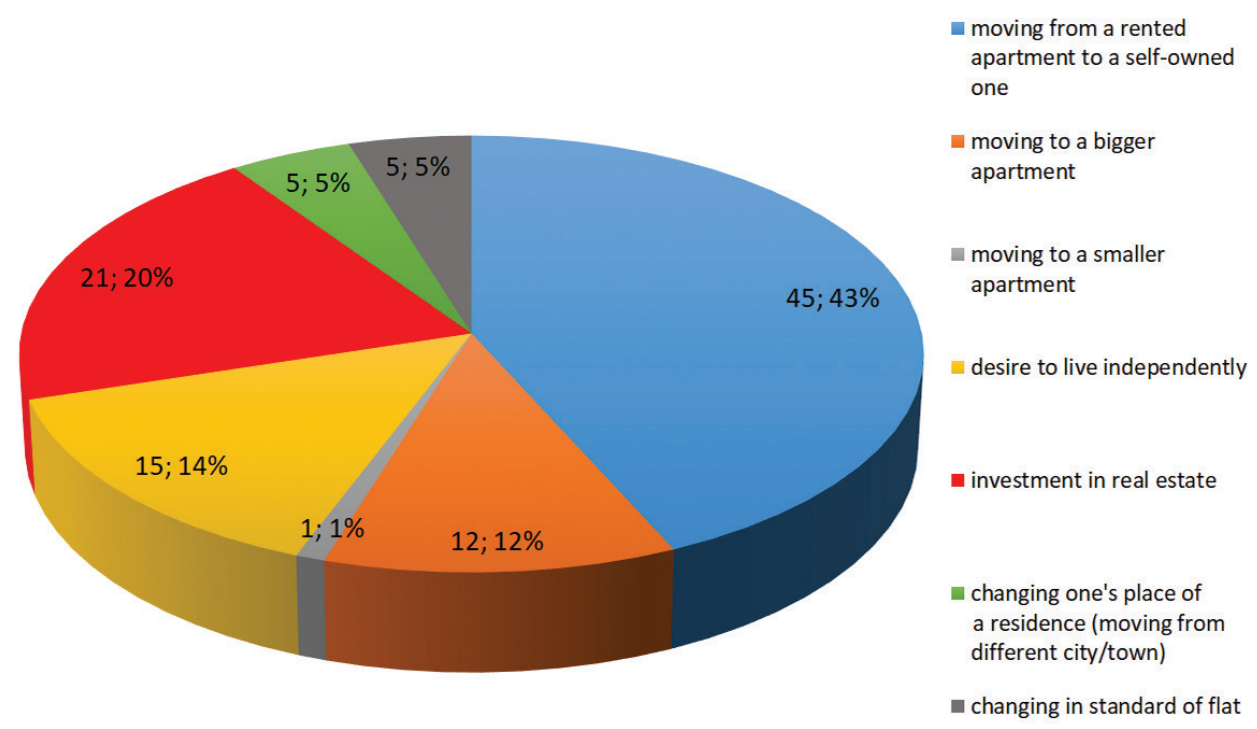

Fig. 2. Motivations for purchasing property as reported by respondents in the city of Krakow

(by authors) 


\subsection{Preferences stated by respondents}

Respondent property preferences were varied and were largely dependent upon the given apartment buyer's individual needs and capabilities.

The study performed by the authors demonstrated that the highest demand was for medium-sized apartments, with potential buyers showing the greatest preference for properties in tall buildings that are up to ten storeys in height (60\% of respondents), while interest in buildings of up to four storeys was declared by $34 \%$ of the respondents, with $6 \%$ of respondents declaring a willingness to purchase an apartment in a building with more than ten storeys. The respondents declared the greatest willingness to purchase an apartment on the first (for the benefit of American readers, 'first' refers to the floor that is one storey above ground level), second or third floor (51\%), with $35 \%$ of respondents showing interest in an apartment at a height between the fourth and tenth floors, 9\% of respondents wanted an apartment on the ground floor, and 5\% of respondents wanted an apartment located above the tenth floor.

Purchasing a property can be funded in various ways, with $71 \%$ of respondents choosing a mortgage, $28 \%$ of respondents choosing personal savings, while one person declared funding an apartment purchase through borrowing money from friends and family. The price of property was not reported to be seen as an indicator of its value, but it often made it unattainable for buyers, with $65 \%$ of the respondents wanting to allocate between 300 to 500 thousand PLN for this purpose. Those interested in cheaper apartments (up to 300 thousand PLN) accounted for $22 \%$ of respondents, with $8 \%$ of respondents aiming to allocate between 500 to 600 thousand PLN for the purchase, while 5\% wanted to allocate more than 600 thousand PLN.

\subsection{Criteria significance}

During the survey, in addition to selecting the size of the preferred apartment, its location and the cost that the respondents were willing to pay for it, the significance of each criterion was reported and rated on a five-point scale ( 1 - the least important, 2 - not very important, 3 - important, 4 - very important, 5 - the most important). Figure 3 presents the average ratings by respondents concerning the significance of each criterion describing both the property itself and its location.

Price was reported as the most significant criterion during a purchase transaction, with the average rating given by respondents being around the 'very important' level, with a score value of 4.1. The layout of the apartment and the number of rooms or floor area were also criteria that were reported to have a very high impact on the selection of an apartment, with the average ratings being 4.0, 3.9 and 3.9, respectively. The least important and therefore the least desirable criteria were the inclusion of a living room kitchenette and a separate toilet. These solutions are declining in popularity among potential apartment buyers, particularly in the case of small apartments that do not include a separate bedroom. The average significance rating for these criteria was 'not very important' and its value for the living room kitchenette was 2.1, while for the separate toilet, it was 2.2. 


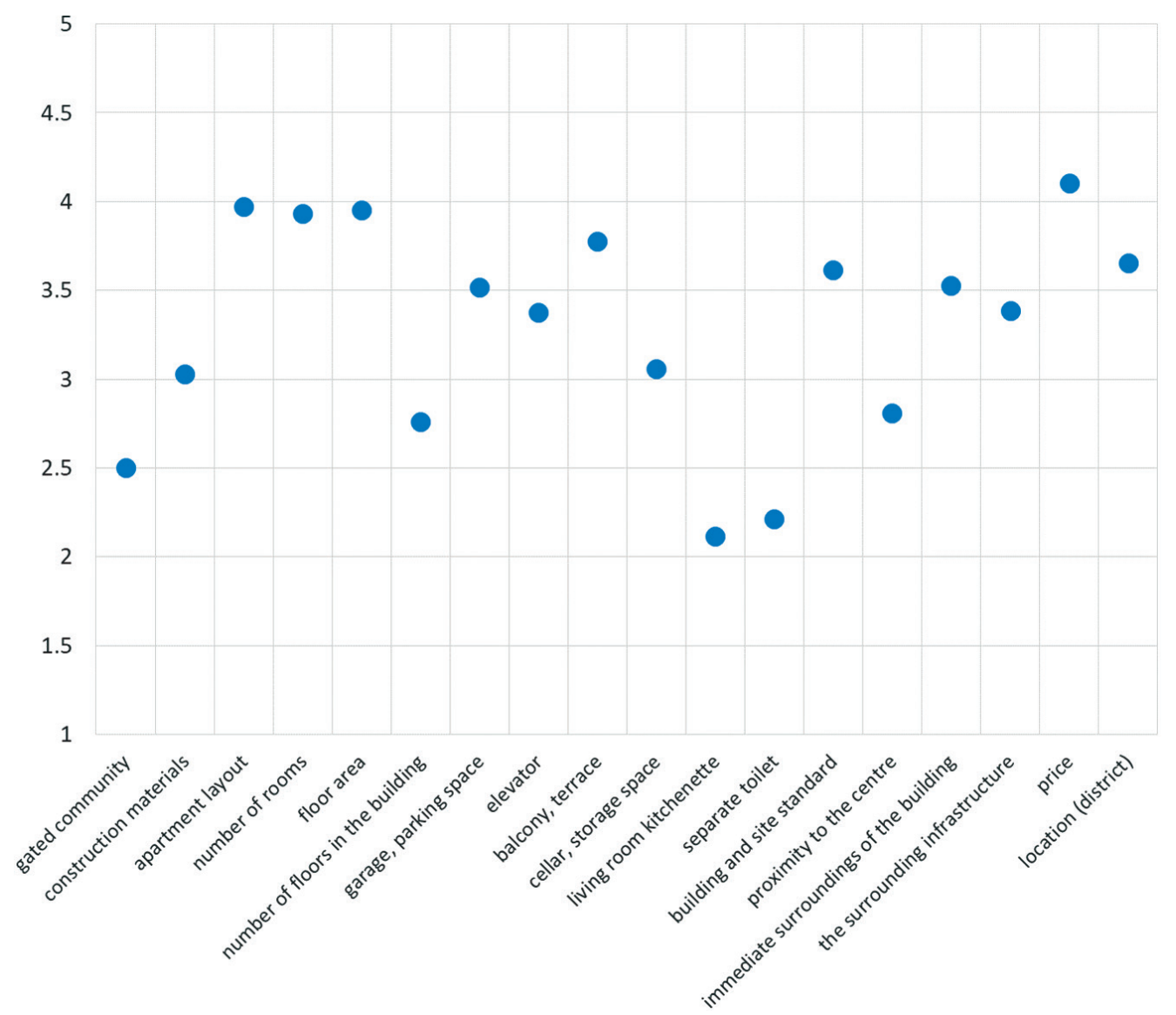

Fig. 3. Significance of individual criteria affecting the selection of a housing property (by authors)

\subsection{Discouraging criteria}

The respondents were also asked to identify criteria that dettered them from purchasing a housing property. Figure 4 features a listing with the criteria arranged in order from the most discouraging to least discouraging.

More than half of the respondents reported that a dangerous neighbourhood was a highly discouraging factor which considerably affected the selection of the location of an apartment to be purchased. A dangerous neighbourhood is understood as an area with a high crime rate, a lack of good illumination and visually unpleasant surroundings. The feeling of safety and comfort increases significantly when monitoring or security personnel are present. Limited public transport connections and property price were discouraging criteria for $38 \%$ of respondents, while $29 \%$ of respondents highlighted a lack of a parking space, with location being reported by $27 \%$. The number of floors in the building, the lack of a cellar or underground storage space, as well as the construction materials that were used were reported to have a negligible impact on apartment selection. 


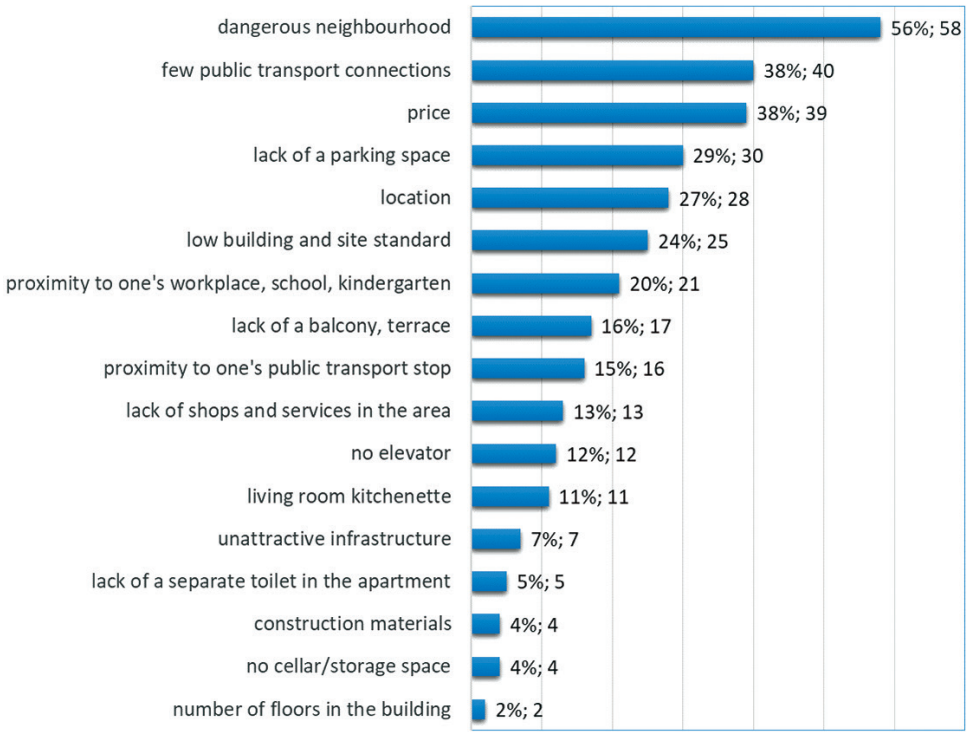

Fig. 4. The most discouraging criteria in the selection of a housing property (by authors)

\subsection{Preferences of selected respondent groups}

Depending on the developer, the same property can be perceived and used differently, and can therefore have different advantages and disadvantages, most significantly including its value. Figures 5 and 6 present the average significance ratings for criteria rated by various groups of people. The criteria affecting the selection of the location of a property were rated.

When comparing the answers given by men and women, we can conclude that both groups have similar requirements in terms of the property to be purchased; however, women rate most criteria higher. The price was the highest-rated criterion in both groups, with the average rating being 3.8 for women and 4.0 for men.

Respondents who searched for an apartment with the intention of moving into it had higher requirements in terms of both the apartments itself and its location. Among those who wanted to purchase property for rent, the most important criterion was accessibility to public transport and quick access to the city centre, which translates to higher attractiveness in the eyes of potential tenants. Considerable differences were observed in the case of proximity to one's place of employment, areas of greenery and a peaceful neighbourhood, with these factors being decidedly more important to future residents than for people who purchase in real estate for rent.

The least important criteria for all groups were the presence of a kindergarten, a school, shopping malls and stores, with their average significance rating amounting to a value of no higher than 2.5.

Criterion key for Figures 5 and 6:

1. Access to public transport

2. Quick access to the city centre 
3. The presence of a nearby parking space

4. Proximity of green areas

5. Proximity to workplace

6. Proximity to a kindergarten or school

7. Proximity to shopping malls/stores

8. Peaceful neighbourhood

9. Noise level

10. Price

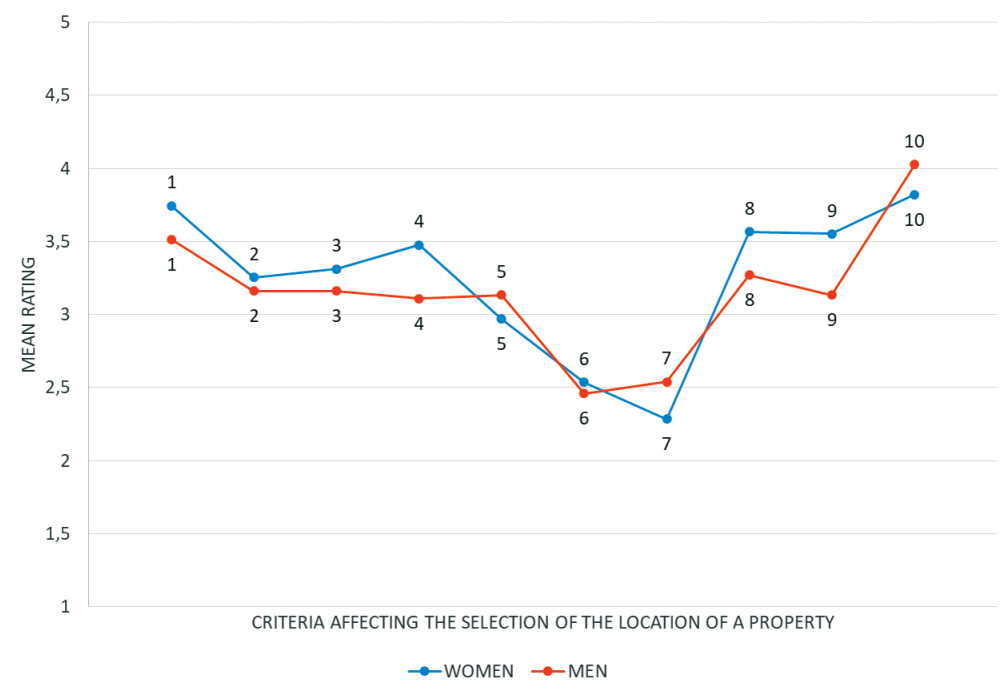

Fig. 5. Average ratings of individual criteria affecting the selection of the location of a property for both men and women (by authors)

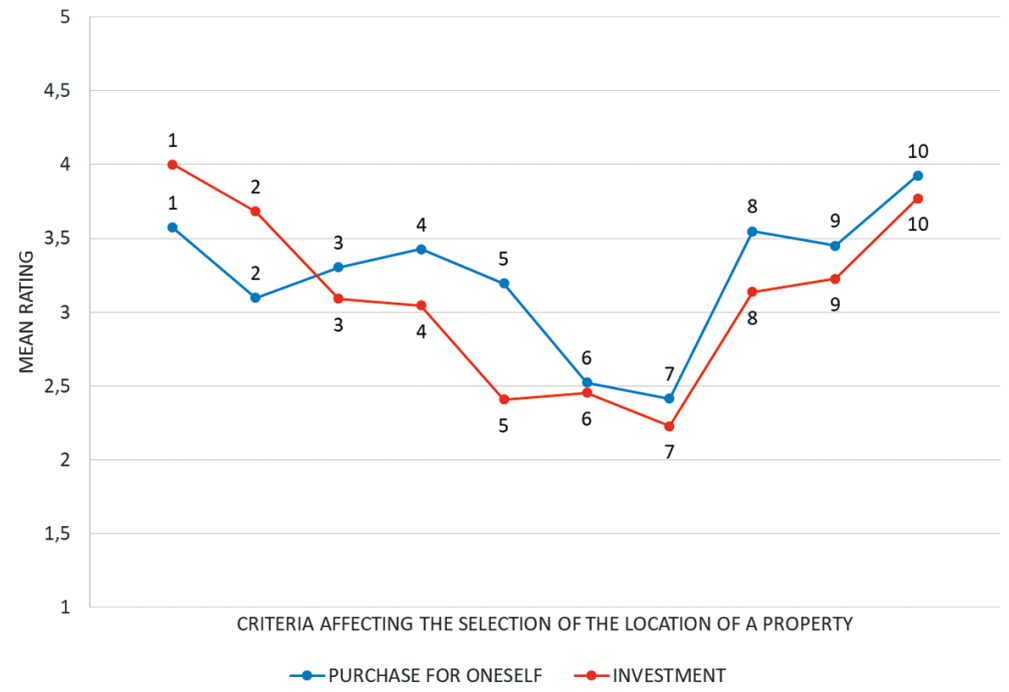

Fig. 6. Average ratings of individual criteria affecting the selection of the location of a property for persons buying the property for themselves and investment buyers (by authors) 


\subsection{Apartment size preferences}

Medium-sized apartments with a usable floor area of between 40 and 60 square metres were reported to attract the greatest amount of interest. However, upon a more precise verification of the database, we can observe a tendency for persons who see purchasing property as an investment to choose apartments that are smaller more frequently than those who are buying for their own needs or those of their loved ones. Figures 7 and 8 present the preferences of respondents concerning apartment size on the basis of the amount of usable floor area and the number of rooms.

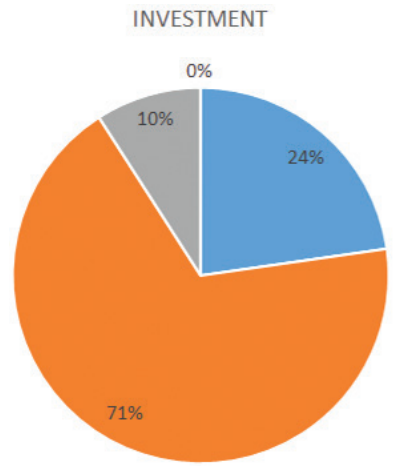

\section{PURCHASE FOR ONESELF}

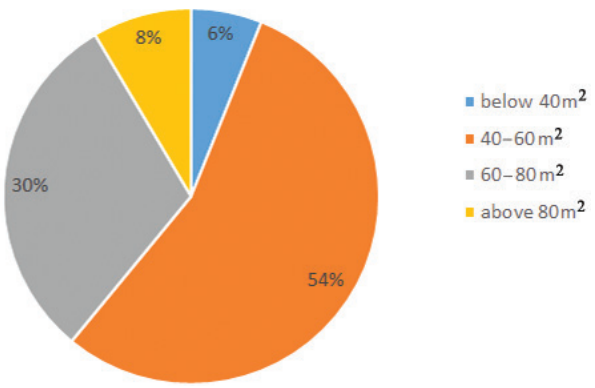

Fig. 7. Preferred usable floor area of the property versus the reason behind the property purchase (by authors)
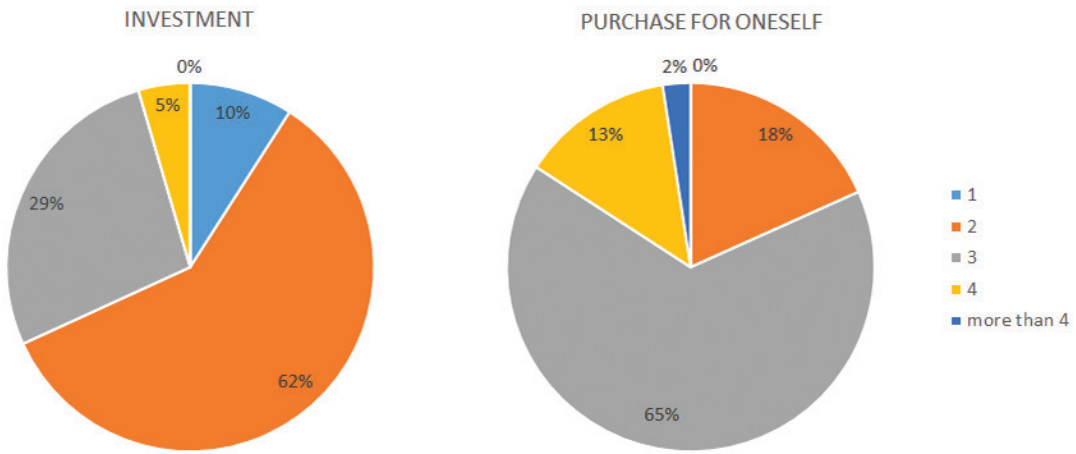

Fig. 8. Preferred number of rooms versus the reason behind the property purchase (by authors)

Persons who expressed a willingness to invest, and thus had the intention of renting out the property after purchase, most often selected two-room apartments (62\%), with 10\% choosing single-room studio apartments, while $29 \%$ preferred three-room apartments and $5 \%$ preferred four-room apartments. None of the respondents expressed interest in a large property with a floor area greater than 80 square metres or a four-room layout.

Among those purchasing the property for themselves, more than half (65\%) preferred three-room apartments, while no one expressed interest in a studio. Two-room apartments were sought by $18 \%$ of the respondents, while a four-room apartment by $13 \%$, with $2 \%$ of potential buyers looking for an apartment with more than four rooms. 


\section{Discussion}

Owning real state is seen as an indicator of one's material status and position in society in both Poland and all over the world, which is why most dream of owning their own apartment or house, with ownership being one of their main life goals. Krakow is a city in which young persons create a demand on the real estate market. The purchase of property is often associated with entering marriage, which is why buyers are most often young, two-person households during their first phase of life who are yet to have children and the purchase of property is treated by them as a long-term investment. The main reason behind purchasing an apartment is to move to a self-owned apartment from a rented property, with the most-often selected form of financing the purchase being a mortgage. The study indicates that housing properties priced at between 300 and 500 thousand PLN that are of medium size and with a usable floor area of between 40 and 60 square metres were the most popular. The layout of the apartment is very important, as is appropriate insulation, the number of rooms and their plan. The apartments selected most often are comprised of three rooms, in addition to a kitchen and a bathroom. A balcony or a small terrace is a considerable asset, increasing the value of an apartment. However, fewer and fewer people are interested in a property where the living room features a kitchenette. A separate toilet is also something that is not seen as popular among persons looking for an apartment.

The study indicates that the relationship between the location and the price is highly significant, as is the presence of transportation nodes or tram and bus lines in the immediate vicinity which can provide quick access to the city centre and any facilities that are important to a potential apartment buyer. Another important and highly regarded aspect is the inclusion of one's own parking space. The aspect that was reported to be the largest deterrent to potential buyers was a dangerous neighbourhood, with buyers preferring a quiet and a peaceful neighbourhood, including a practical and functional arrangement of the space around the building, which also leads to an increased feeling of comfort and safety.

Persons who want to rent their property are more likely to select smaller, two-room apartments. In this case, it is important for the apartment to be located close to public transport links that can provide quick access to the city centre. Larger properties were selected decidedly more often by persons who were searching for an apartment for themselves. Close proximity to one's workplace and a peaceful neighbourhood in an area with low noise levels were valued considerably higher. The price was the most important criterion for all potential apartment buyers.

\section{Conclusions}

The survey study performed on a group of persons who were looking to buy property in Krakow indicates the preferences of potential buyers. The primary objective of the work was to identify the requirements that come into play during the search for an apartment, to define the group that creates the demand and to highlight the differences in requirements arising 
from the motivations behind the purchase of property. Analysis of the data revealed the most important criteria considered by buyers during the selection of a property and its location, including the most discouraging criteria.

Krakow's housing market is constantly developing, with developers building increasingly modern apartments, while more and more renovated and attractive apartments in townhouses appear on the secondary market; this situation enables everybody to find their dream apartment. The selection of a property is a decision that affects us over the long term and is affected by various factors, including financial capabilities and trends. In order to meet the requirements of clients, companies should pay particular attention to the preferences of potential buyers. As a result of adopting a stance that favours satisfying needs and appropriate marketing measures, developers are able to meet these requirements by developing their offering and becoming successful in the real estate sector.

Based on the results of the study, it can be concluded that the perfect apartment for the majority of buyers has between 40 and 60 square metres of usable floor area, is composed of three rooms, in addition to a kitchen and a bathroom, and has its own dedicated parking space. Such apartments should be located in ten-storey buildings, on the first, second or third floor, and be in close proximity to transportation nodes. In order to increase security, the building and its neighbourhood should be monitored and be equipped with an alarm system. Potential apartment buyers are prepared to pay more for a property that meet all of these requirements. The study is an important indication for developers, who can increase the prices of the apartments for which the demand is highest.

\section{References}

[1] Affuso E., Caudill, S.B., Mixon F.G., Starnes K.W., Is Airport Proximity an Amenity or Disamenity? Empirical Investigation Based on House Prices, Univ Wisconsin Press, Journal Division, 2019.

[2] Belniak M., Radziszewska-Zielina E., Effectiveness of Applying Marketing Tools in Real Estate Trading, IOP Conference Series: Materials Science and Engineering 471(11), 112074, 2019.

[3] Bimonte S., Stabile A., The impact of the introduction of Italian property tax on urban development: a regional regression model, Routledge Journals, 2019.

[4] Butryn K., Preweda E., The primary market of parking places against the background of the primary housing market and planning policy on the example of Krakow, International Conference on Environmental Engineering, ICEE, 2017.

[5] Del Giudice V., De Paola P., Francesca T., Nijkamp, P.J., Shapira, A., Real Estate Investment Choices and Decision Support Systems, MDPI, 2019.

[6] Farraz M.A., Barus L.S., Housing Preferences and Choice Young Families Commuters in Depok City, Indonesia, IOP Conference Series: Earth and Environmental Science 264(1), 2019. 
[7] Flambard V., Demand for housing choices in the north of France: a discrete approach, Emerald Group Publishing LTD, 2017

[8] Głuszak M., Externalities and house prices: A stated preferences approach, Entrepreneurial Business and Economics Review 6(4), 2018, 181-196.

[9] Gluszak M., Marona B., Discrete choice model of residential location in Krakow, Journal of European Real Estate Research 10(1), 2017, 4-16.

[10] Heyman A.V., Sommervoll D.E., House prices and relative location, Cities 95, 2019.

[11] Kowalczyk C., Kil J., Kurowska K., Dynamics of development of the largest cities - Evidence from Poland, Cities 89, 2019, 26-34.

[12] Rivas R., Patil D., Hristidis V., Barr J.R., Srinivasan N., The impact of colleges and hospitals to local real estate markets, Journal of Big Data 6(1), 7, 2019.

[13] Szczepańska A., Residential property market in the functional urban area of Olsztyn in the context of demographic changes, Real Estate Management and Valuation 25(3), 2017, $30-39$.

[14] Trojanek R., Gluszak M., Spatial and time effect of subway on property prices, Journal of Housing and the Built Environment 33(2), 2018, 359-384.

[15] Tsai Y.S., Chang C.P., Tzang S.W., Demographic Structure, Business Fluctuations, Tax Shock and Housing Bubbles, Advances in Intelligent Systems and Computing 994, 2019, $727-737$.

[16] Zhang L., Zhou J., Hui E.C.M., Wen H., The effects of a shopping mall on housing prices: A case study in Hangzhou, International Journal of Strategic Property Management 23 (1), 2019, 65-80. 
